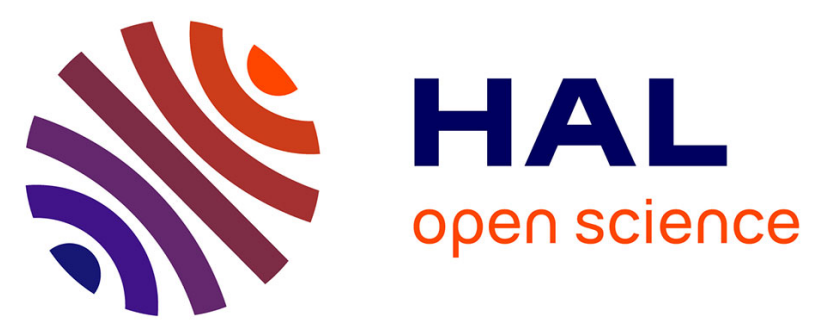

\title{
The larval provisions of the crop pollinator Centris analis: pollen spectrum and trophic niche breadth in an agroecosystem
}

Ricardo Santos, Cândida Aguiar, Marcos C. Dórea, Gesline Almeida, Francisco A. R. dos Santos, Solange Augusto

\section{To cite this version:}

Ricardo Santos, Cândida Aguiar, Marcos C. Dórea, Gesline Almeida, Francisco A. R. dos Santos, et al.. The larval provisions of the crop pollinator Centris analis: pollen spectrum and trophic niche breadth in an agroecosystem. Apidologie, 2013, 44 (6), pp.630-641. 10.1007/s13592-013-0211-z . hal-01201331

\section{HAL Id: hal-01201331 \\ https://hal.science/hal-01201331}

Submitted on 17 Sep 2015

HAL is a multi-disciplinary open access archive for the deposit and dissemination of scientific research documents, whether they are published or not. The documents may come from teaching and research institutions in France or abroad, or from public or private research centers.
L'archive ouverte pluridisciplinaire HAL, est destinée au dépôt et à la diffusion de documents scientifiques de niveau recherche, publiés ou non, émanant des établissements d'enseignement et de recherche français ou étrangers, des laboratoires publics ou privés. 


\title{
The larval provisions of the crop pollinator Centris analis: pollen spectrum and trophic niche breadth in an agroecosystem
}

\author{
Ricardo M. Santos ${ }^{1}$, Cândida M. L. Aguiar ${ }^{2}$, Marcos da C. Dórea ${ }^{3}$, \\ Gesline F. Almeida ${ }^{2}$, Francisco de A. R. dos Santos ${ }^{3}$, Solange C. Augusto ${ }^{4}$ \\ ${ }^{1}$ PPG Zoologia-UEFS, Universidade Estadual de Feira de Santana, 44036-900 Feira de Santana, Bahia, Brazil \\ ${ }^{2}$ Laboratory of Entomology, Departamento de Ciências Biológicas, Universidade Estadual de Feira de Santana, Av. \\ Transnordestina, s/n, Novo Horizonte, 44036-900 Feira de Santana, Bahia, Brazil \\ ${ }^{3}$ Laboratory of Plant Micromorphology, Departamento de Ciências Biológicas, Universidade Estadual de Feira de \\ Santana, 44036-900 Feira de Santana, Bahia, Brazil \\ ${ }^{4}$ Instituto de Biologia, Universidade Federal de Uberlândia, 38400-902 Uberlândia, Minas Gerais, Brazil
}

Received 1 November 2012 - Revised 8 April 2013 - Accepted 17 April 2013

\begin{abstract}
This study aimed to characterize the importance of the sources of floral resource used by Centris analis to provision nests in acerola orchards (the West Indian cherry, Malpighia emarginata). Thirty-six pollen types were recognized in larval provisions, of which the most frequently found were M. emarginata (76 \%), Cajanus cajan (11\%), Chamaecrista type 1 (3\%), and Solanum paniculatum (3\%). The pollen-type M. emarginata was registered in $98 \%$ of the brood cells, with monthly frequencies from 30 to $99 \%$. The trophic niche breadth $\left(H^{\prime}\right)$ of the larvae of $C$. analis was 1.24 , with monthly variations from 0.04 to 1.44 . The richness of pollen types found in larval provisions of $C$. analis may be considered high compared to results obtained in other agrosystems with cultivated acerola. The high relative frequency of the pollen-type M. emarginata strongly affected trophic niche breadth and equitativity in the use of food resources. This crop provides floral resources (pollen and floral oils) needed by the pollinator $C$. analis throughout the year in the region.
\end{abstract}

entomopalynology / floral resources / solitary bees / Centridini / crop pollinator

\section{INTRODUCTION}

The floral resources pollen, nectar, and oil are essential for the reproduction of Centris bees, an important group of pollinator bees. Most of these bees use floral oil as larval food and/or building material mainly for inner coating of brood cells and/or outer coating of the nest plug (Vinson and Frankie 2000; Jesus and Garófalo 2000). Therefore, identification of plants that provide food resources needed for

Corresponding author: C.M.L. Aguiar,

candida.aguiar@gmail.com

Manuscript editor: Klaus Hartfelder maintaining populations of Centris in different regions is a crucial step to define conservation strategies and provide information for the development of a management system for these species aiming at crop pollination.

Most studies on the use of floral resources by bees have been conducted by capturing bees while they are visiting flowers. This sampling method results in the collection of small samples of several species, not allowing for safe conclusions on the importance of some sources of resources used by each one of the species nor on the breadth and overlap of trophic niches. Cane and Sipes (2006) argued that taxonomic identification and numerical analysis of the pollen collected by bees 
to provision their brood cells offer a more straightforward and quantitative method for assessing bee diet breadth, with advantages over field observations. The analysis of nest-stored pollen has been widely used in research on the floral resources used by social bees in Brazil since the 1980s (Cortopassi-Laurino and Ramalho 1988; Ramalho et al. 1989, among others). However, only recently, this methodology was used in studies of trophic niches of both solitary and parasocial native bees, such as Euglossa annectans (Cortopassi-Laurino et al. 2009), Epicharis nigrita (Gaglianone 2005), and some species of Centris such as Centris tarsata (Dórea et al. 2010a; Gonçalves et al. 2012), Centris caxiensis, Centris leprieuri, Centris aenea (Ribeiro et al. 2008), and Centris analis (Oliveira and Schlindwein 2009; Dórea et al. 2010b; Rabelo et al. 2012). Recently, Vilhena et al. (2012) used palynological data to study the use of pollen resources by several species of Centris and the pollination network Centridini bee-plants. The pollen resources used by species of Centris have also been under study in other tropical regions (Quiroz-Garcia et al. 2001; QuirozGarcia and de la Arreguin-Sánchez 2006; Roubik and Villanueva-Gutiérrez 2009). Recently, Roubik and Villanueva-Gutiérrez (2009) also analyzed the pollen of larval provisions of $C$. analis to assess the impact of the exotic bee Apis mellifera on this native bee.

Few research studies on the food resources used by species of Centris in agroecosystems are available (Oliveira and Schlindwein 2009; Vilhena et al. 2012) in spite of their known importance as potential pollinators of several crops (Freitas et al. 1999, 2002; Freitas and Paxton 1998; Gaglianone et al. 2010) and of the fact that traits found in some of its species may lead to the possibility of management for crop pollination. Also recently, Oliveira and Schlindwein (2009) analyzed the larval provisions of $C$. analis in nests established in acerola orchards (the West Indian cherry Malpighia emarginata) and emphasized the large potential for the species to be managed as an acerola pollinator in Brazil. However, a management system for $C$. analis can only be developed after studies on the resources needed for maintaining its population in different regions, a gap this work will help to fill, as well as on other issues of its population biology not addressed in this study.

Our study was conducted to enhance knowledge on the food resources required to sustain pollinator bee populations in acerola orchards by identifying and characterizing the importance of each source of floral resource used by C. analis to provision nests in a crop area in northeastern Brazil. These data will be useful to recognize differences in the diet of populations living in crop areas in different regions where M. emarginata has been cultivated.

\section{MATERIALS AND METHODS}

\subsection{Research site}

Sampling was conducted in Feira de Santana, state of Bahia, Brazil. The regional climate is tropical semiarid, with rainfall approximately $800 \mathrm{~mm} /$ year and rains concentrated between November and May, and a mean annual temperature of $24{ }^{\circ} \mathrm{C}$ (CEI 1994). The acerola orchard of approximately 350 trees was located in a 2-ha family farm $\left(12^{\circ} 17.3^{\prime} \mathrm{S} / 38^{\circ} 58.9^{\prime} \mathrm{W}\right)$. Cassava (Manihot sculenta), corn (Zea mays), beans (Phaseolus vulgaris), and pigeon peas (Cajanus cajan) were grown in small plots both within the farm and in nearby family farms. Although sparse, both ruderal plants and plants of agricultural importance (Anacardium occidentale, Tamarindus indica, and Mangifera indica) were found.

\subsection{Sampling and analysis of the larval provisions}

Trap nests made of cardboard straws, measuring $8 \mathrm{~mm}$ in diameter and 5 and $10 \mathrm{~cm}$ in length, were inserted in perforated wooden blocks and placed in the orchard to obtain both the nests of $C$. analis and the samples of the pollen used to provision the brood cells. Nests were collected once a month for 12 months (September 2009 to August 2010). They contained offspring in the egg stage or larva of the first instars. Following nest removal, two nests of $C$. analis were open each month for collection of stored pollen. The nests of $C$. analis were identified 
following the description by Jesus and Garófalo (2000), according to nest architecture (mainly the presence of a vestibular cell) and the plant material used to build the brood cells. Larval provisions found in other eight nests of $C$. analis established between November 2008 and April 2009 in the same orchard also were collected using the same methods. Each sample consisted of the pollen collected from each brood cell, a total of 55 samples obtained from 32 nests. Each pollinic sample was kept for at least $24 \mathrm{~h}$ in glacial acetic acid. The samples were treated by acetolysis (following Erdtman 1960). Five slides were prepared for each sample; safranin-colored glycerin jelly was used in three slides. At least 200 pollen grains were counted in each slide, a minimum total of 1,000 grains for each brood cell and a total of 63 thousand grains. The term "pollen type" was used to refer to the morphological type of pollen grain, following Joosten and Klerk (2002). The pollen types were photographed and identified by comparison either with the specialized bibliography or with the reference materials available in the palynotheca at Plant Micromorphology Laboratory, Universidade Estadual de Feira de Santana.

The monthly and total relative frequencies (RF) of each pollen type were calculated by the ratio between the number of grains of each registered pollen type (monthly and in the whole period) and the total number of grains counted each month and during the whole sampling period, respectively. We recognized a plant species as a pollen source if the relative frequency of the pollen type was higher than $10 \%$ in one or more months and if there are published data referring to the pollen production by that plant. The trophic niche breadth of larvae was calculated using the Shannon index $\left(H^{\prime}=-\sum p k \times \ln p k\right)$, where $p k$ is the ratio between the number of counted grains for each pollen type $(k)$ and the total number of counted pollen grains. The equitativity in the use of sources of floral resources by $C$. analis was calculated using the Pielou index $\left(J^{\prime}=H^{\prime} / H_{\text {max }}^{\prime}\right)$.

Sample constancy (SC) was calculated as the ratio between the number of samples where each pollen type occurred and the total number of analyzed samples $(n=55)$ and was used to assess the distribution (presence/absence) of each pollen type among the 55 samples. The distribution of each pollen type throughout the sampling period was obtained by calculating the temporal constancy (TC) of each pollen type as the ratio between the number of months when each pollen type was registered and the total number of months analyzed $(n=18)$. We used pollen incidence data to build a rarefaction curve and to compare the observed with the expected richness of pollen types using the estimators Chao 2, Jacknife first order (Jack 1), and bootstrap, randomized 100 times, with Estimates v. 7.5.2 (Colwell 2005).

Data on the monthly abundance of acerola flowers in this orchard were collected from 14 marked plants, from September 2009 through August 2010. The objective was to support the evaluation of the importance of acerola pollen as larval food for $C$. analis based on the number of pollen grains. These data are also useful to determine whether the availability of floral resources of $M$. emarginata affects the collection of floral resources from other plants by nesting females. Flowers and flower buds were counted monthly, one branch per treetop quadrant (north, east, south, and west) of each marked tree, a total of four branches per tree.

\section{RESULTS}

\subsection{Relative frequency and constancy of pollen types in the samples}

Thirty-six pollen types from 20 botanical families were found in the larval provisions of C. analis (Table I). Seven of them were seldom registered (one to two grains) and may not show plants visited by $C$. analis for the collection of floral resources. Two to 11 pollen types were found per brood cell. The rarefaction curve showed that more pollen types would probably be added with increasing sampling effort. Comparison of the rarefaction analyses with the number determined by Chao 2, Jack 1, and bootstrap richness estimators revealed that $74.1-85.8 \%$ of the estimated richness of pollen types was covered by the sampling effort (Figure 1).

Leguminosae, Malpighiaceae, and Malvaceae had the greatest richness of pollen types $(8,4$, and 4 , respectively) registered in brood cells of C. analis. By grouping the relative frequencies 


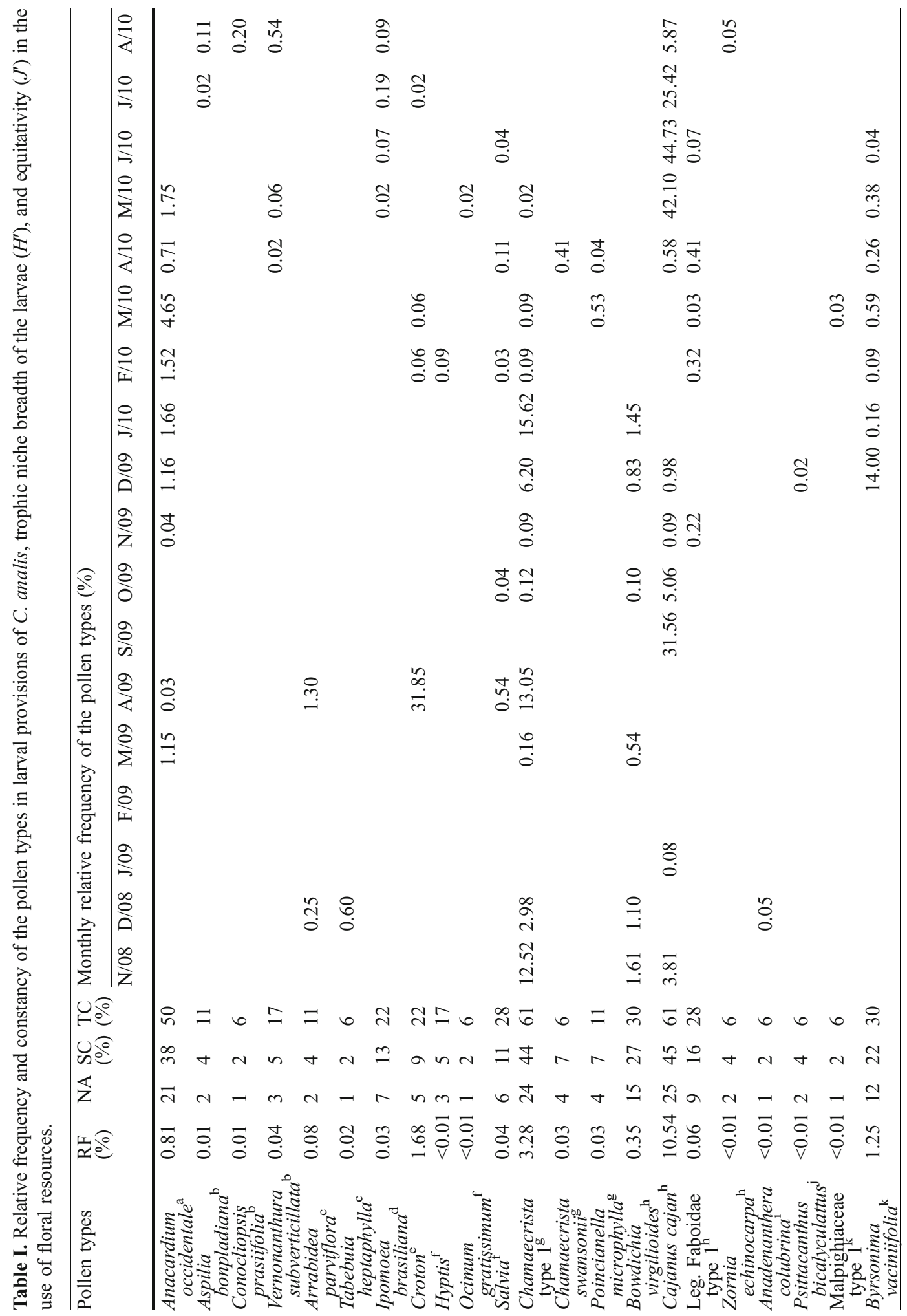




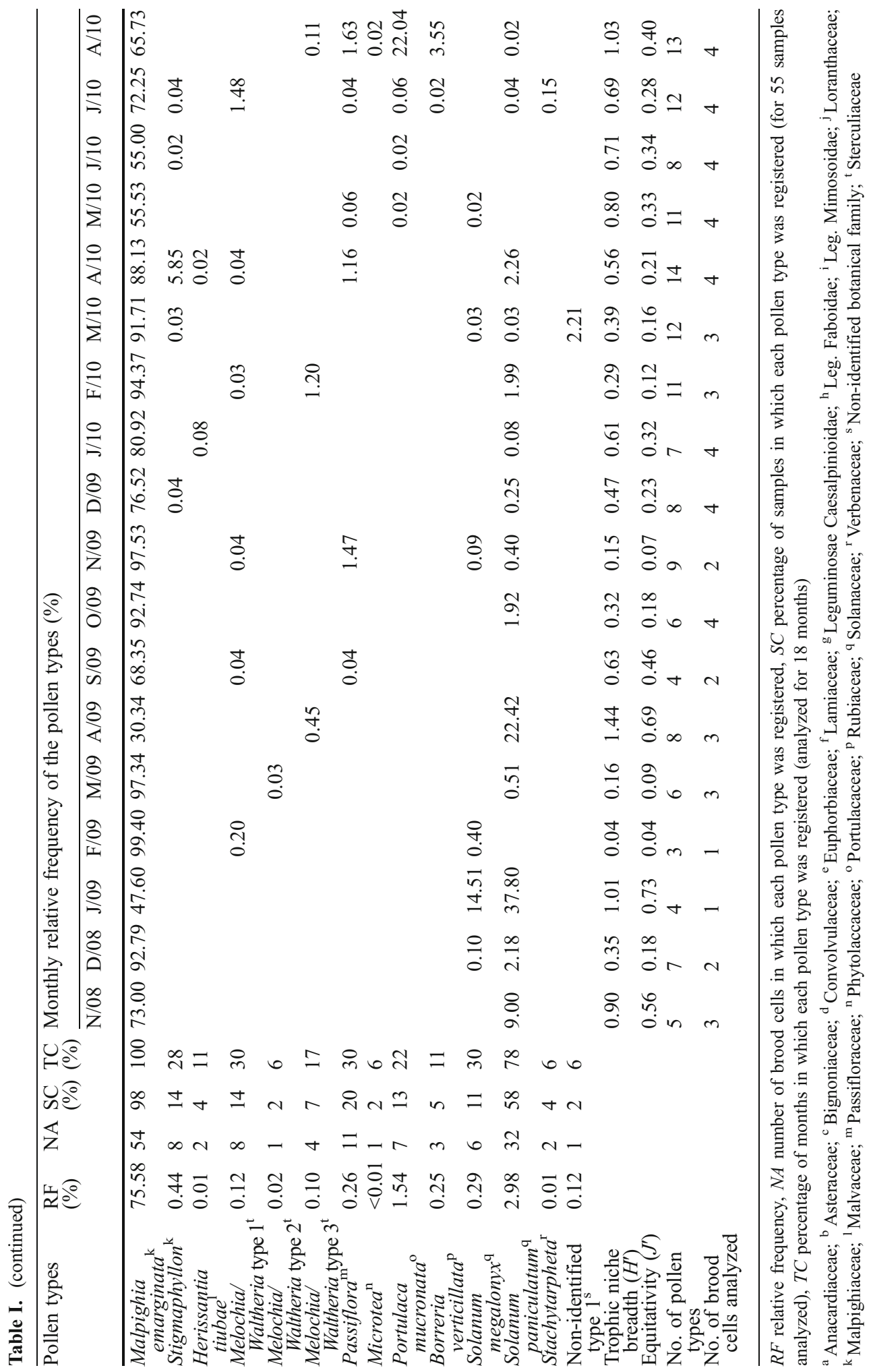




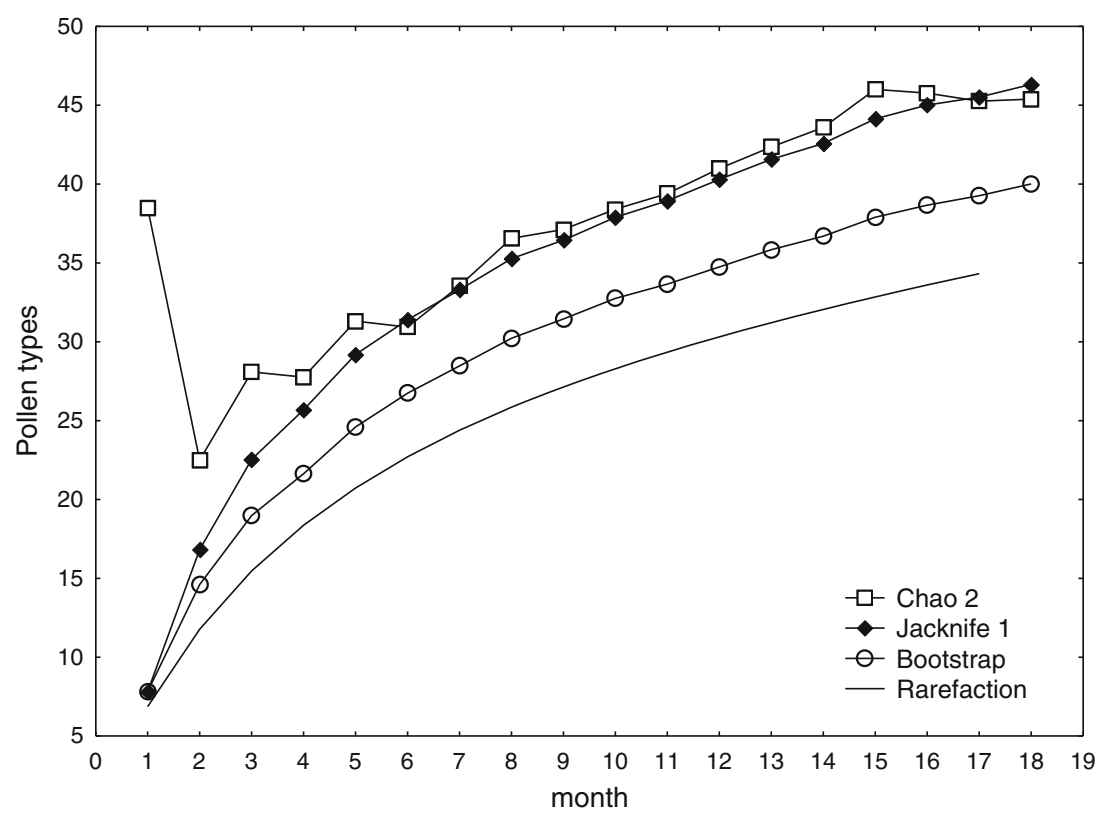

Figure 1. Rarefaction curve and richness estimators (Chao 2, Jack 1, and bootstrap) of pollen types in larval provisions of $C$. analis from an agroecosystem in Feira de Santana, Brazil.

of the pollen types per botanical family, we observed that Malpighiaceae, Leguminosae, and Solanaceae had the highest quantitative importance in the diet of the larvae of $C$. analis. Altogether, the four pollen types related to Malpighiaceae represented $77.3 \%$ of the total pollen grains counted, whereas the pollen types related to Leguminosae and Solanaceae represented 14.3 and $3.3 \%$ of the total, respectively.

Four pollen types were the most representative in the samples: $M$. emarginata (Malpighiaceae), with the highest relative frequency $(75.6 \%$ of the total pollen grains counted), followed by C. cajan (Leguminosae) (10.5\%), Chamaecrista type 1 (Leguminosae, $3.3 \%$ ), and Solanum paniculatum (Solanaceae, $3.0 \%$ ). Twenty-nine of the 36 pollen types occurred at $<1 \%$ frequency (Table I). $M$. emarginata had the highest relative frequency every month, except for April 2009, being thus the most important pollen type in the diet of larvae of C. analis. Its monthly frequency varied from $99.4 \%$ (February 2009) to $30.3 \%$ (April 2009) and was usually above $60 \%$ (Table I). The pollentype $C$. cajan was more important in the diet of larvae of C. analis in September 2009 and from May to July 2010. Chamaecrista type 1 was more important in November 2008, August 2009, and January 2010, whereas $S$. paniculatum was one of the most frequently found in provisions of $C$. analis in November 2008 and in January and April 2009. Pollen types with low total relative frequencies were important in the diet of larvae of C. analis in isolated months, such as Portulaca mucronata, Croton, Byrsonima vaciniifolia, and Solanum megalonyx (Table I).

The analysis of SC of pollen types revealed the presence of $M$. emarginata in 54 of the 55 brood cells studied ( $\mathrm{SC}=98 \%$ \%). Other pollen types with high constancy were $S$. paniculatum $(\mathrm{SC}=58 \%), C$. cajan $(\mathrm{SC}=45 \%)$, and Chamecrista type $1 \quad(\mathrm{SC}=44 \%)$. Eight types were present in only 1 of the 55 brood cells analyzed, with very low constancy (Table I). Five pollen types were found in larval provisions of $C$. analis for longer periods of time, thus with high TC: $M$. emarginata, registered during the 18 months $(\mathrm{TC}=100 \%)$, S. paniculatum (14 months, TC=78\%), C. cajan and 
Chamaecrista type 1 (11 months, TC=61\%), and $A$. occidentale ( 9 months, TC $=50 \%$; Table I).

\subsection{Trophic niche breadth}

The trophic niche breadth of larvae of $C$. analis for the whole sampling period was 1.24. Monthly breadths varied from 0.04 to 1.44 , usually below 1.00 (Table I), except for January and April 2009 and August 2010 when the highest values were found $\left(H^{\prime}=1.01,1.44\right.$, and 1.03 , respectively). The frequency of the pollen of $M$. emarginata in the diet of larvae of $C$. analis during these months was a little lower than in most months, particularly in January and April 2009, when the monthly frequencies in the samples were 48 and $30 \%$, respectively (Table I). During these months, the highest equitativities in using floral resources were also observed $\left(J^{\prime}=0.73\right.$ in January and $J^{\prime}=0.69$ in April 2009) as a result of the numerical increase of other pollentypes in the provisions. In April 2009, when the trophic niche breadth of larvae of $C$. analis was the highest $\left(H^{\prime}=1.44\right)$, eight pollen types were registered in the larval provisions. Among these, Croton (32\% of monthly relative frequency), M. emarginata (30\%), S. paniculatum (22\%), and Chamaecrista type 1 (13\%) were important as floral resources for larvae. In January $2009\left(H^{\prime}=1.01\right)$, in addition to the pollen of $M$. emarginata (48 \%), two other pollen sources were important: $S$. megalonyx (14\%) and, mainly, S. paniculatum (38\%). In August $2010\left(H^{\prime}=1.03\right), M$. emarginata (66\%) and P. mucronata (22\%) were the most important sources of pollen for $C$. analis (Table I).

From September 2009 through August 2010, when data on acerola flowering were collected, the larvae of $C$. analis had the highest trophic niche breadth in months when acerola plants were not blooming in this orchard, such as August $\left(H^{\prime}=\right.$ $1.03)$ and May $\left(H^{\prime}=0.80\right.$; Figure 2 and Table I). The number of pollen types registered was high (13 in August and 11 in May), leading to higher trophic niche breadths. Nevertheless, acerola pollen continued to be one of the important components (56-66\% of the counted grains) of the larval provisions of $C$. analis during these months. The equitativity in the use of resources was relatively low in this period $\left(J^{\prime}=0.40\right.$ in August, $J^{\prime}=0.33$ in May) due to the major contribution of few pollen types (M. emarginata, P. mucronata, and C. cajan) for the composition of the larval provisions. During that period, the lowest values were recorded for trophic niche breadth both in months of low acerola flower production, such as October $2009\left(H^{\prime}=0.32\right)$, November $2009\left(H^{\prime}=0.15\right)$, and February 2010 $\left(H^{\prime}=0.29\right)$, and in months of high flower production, such as March $2010\left(H^{\prime}=0.39\right.$; Figure 2 and Table I). Common to all months with low trophic niche breadths were the importance of $M$. emarginata in larval diet (between 92 and $98 \%$ ) and the low equitativity in resource use $\left(J^{\prime}=0.07-\right.$ 0.18 ; Table I).

\section{DISCUSSION}

\subsection{Richness of the sources of floral resources}

The richness of pollen types found in the larval provisions of $C$. analis in our study may be considered high compared to the results obtained in two different areas with acerola, with three and six pollen types registered in the larval provisions of C. analis (Oliveira and Schlindwein 2009). Quiroz-Garcia et al. (2001) recognized 17 pollen types in the larval provisions of $C$. analis in a tropical decidual forest in Mexico. The richness of the pollen types found in our study may be related to the presence of ruderal plants within and around the orchard, considering that the removal of ruderal plants is not a frequent agricultural practice in local farms. The richness of pollen types registered in our study may also have been due to the length of the sampling period (18 months) and the number of nests $(n=32)$ and brood cells, which were higher than in similar studies (Quiroz-Garcia et al. 2001; Oliveira and Schlindwein 2009; Dórea et al. 2010b), where pollen samples were collected from nests in 14 months or both. On the other hand, more pollen types would probably be added with increasing sampling effort in our study. The strongest 


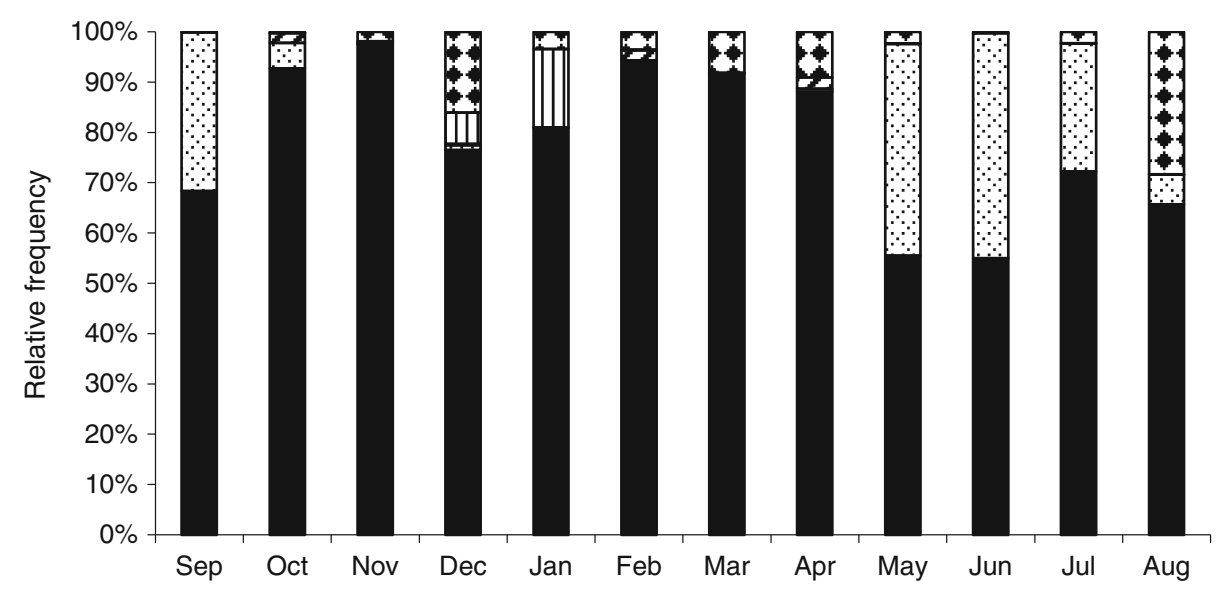

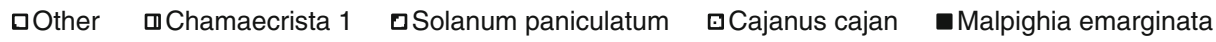

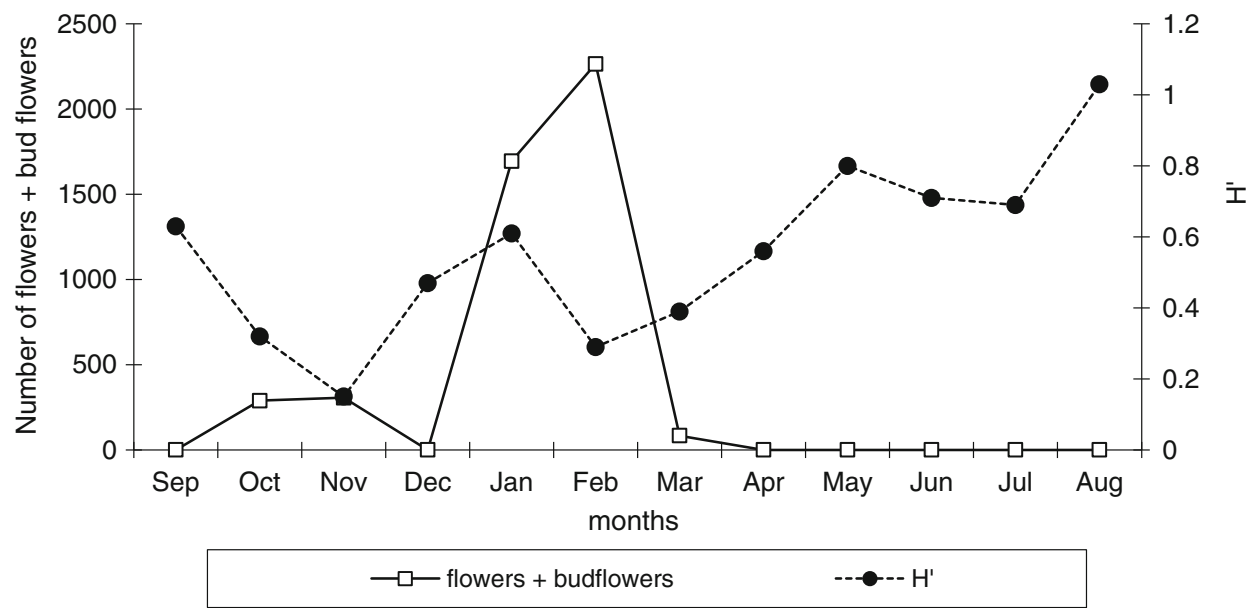

Figure 2. Monthly relative frequency of the most common pollen types in provisions of $C$. analis, $H^{\prime}$ index, and flowering periods of acerola (M. emarginata) in a tropical agroecosystem.

evidence that the number of nests and sampling period affect the richness of the pollen types found in larval provisions of $C$. analis has been provided by Roubik and Villanueva-Gutiérrez (2009) in a 9 -year study conducted in a mature forest in Mexico. They collected a large number of nests $(n=350)$ and found 72 species of plants used as major pollen resources by $C$. analis. They observed large variations in the richness of pollen types in nests of $C$. analis and megachilids in different years and concluded that the summed richness in the major pollen resources for $C$. analis was related to the number of nests examined, suggesting that $C$. analis is generalist in pollen choice.

\subsection{Use of pollen, nectar, and floral oils}

Five pollen types had higher temporal constancy in larval provisions of $C$. analis. Four of them (M. emarginata, C. cajan, S. paniculatum, and Chamaecrista type 1) had a relative frequency over $10 \%$ in at least 2 months. This suggests that the plant species related to these pollen types are 
visited by females of $C$. analis to obtain pollen. Studies have shown that $M$. emarginata and $S$. paniculatum provide pollen for Centris bees in other regions (Aguiar et al. 2003; Oliveira and Schlindwein 2009; Dórea et al. 2010a). Chamaecrista type 1, a pollen type related to pollen provider plant species (Aguiar et al. 2003; Dórea et al. 2010a), was recorded in larval provisions of $C$. analis in 11 months. However, its low frequency indicates that the species is a somewhat important source of pollen in the diet of larvae of $C$. analis in short periods of time, the same occurring with $P$. mucronata, Croton, B. vaciniifolia, and $S$. megalonyx. Croton has been recognized as a source of pollen to A. mellifera ("secondary pollen," with percentage between 15 and $45 \%$ ) based on the frequency of that pollen type in pollen samples (Novais et al. 2009).

The choice of pollen sources by females of $C$. analis in the study site had a relatively narrow spectrum, or eight pollen types. The most frequent and/or the most constant ones were $M$. emarginata, C. cajan, Chamaecrista type 1, and $S$. paniculatum, whereas Croton, $P$. mucronata, $B$. vaciniifolia, and $S$. megalonyx were less important. Pollen types related to other plant species mentioned in the literature as pollen sources for bees were not frequent enough in our study (relative frequency of $<10 \%$ in all months analyzed) to be included as pollen resources for females of $C$. analis. Other palynological studies of larval provisions in natural vegetation have shown similar trends of foraging concentration on a few pollen resources by C. analis (QuirozGarcia et al. 2001; Dórea et al. 2010b; Roubik and Villanueva-Gutiérrez 2009; Rabelo et al. 2012) and other species of the genus, such as Centris nitida (Quiroz-Garcia et al. 2001), C. tarsata (Dórea et al. 2010a), and Centris trigonoides (Quiroz-Garcia et al. 2001). Dórea et al. (2010b) recognized three pollen sources for C. analis (Banisteriopsis muricata, B. vaciniifolia, and Chamaecrista ramosa), whereas three pollen sources were recognized for $C$. tarsata (C. ramosa, Senna rizzini, and $S$. paniculatum; Dórea et al. 2010a). Roubik and Villanueva-Gutiérrez (2009) found six major pollen genera for C. analis, constituting $70 \%$ of the pollen stored in the nests. This study by Roubik and Villanueva-Gutierrez (2009) showed that $C$. analis substitutes for major pollen sources in different years and that the richness of pollen types stored in its nests may vary significantly from year to year, with one to nine dominant pollen species shared between years.

The high relative frequency of the pollen of $M$. emarginata in the larval provisions of $C$. analis in the studied orchard makes it the main pollen source for this species of Centris, as found by Oliveira and Schlindwein (2009) in acerola orchards near the Atlantic Forest in northeastern Brazil. For them, the abundance of pollen and floral oils in acerola orchards reduces the energy costs by females while foraging, which may explain the high fidelity of $C$. analis to flowers of $M$. emarginata in crop areas. B. vaciniifolia, Stigmaphyllon, and Malpighiaceae type 1 had low level of representation in provisions of $C$. analis in our study, indicating that the plant species related to these pollen types are locally used as floral oil sources, but there is also an indication that $B$. vaciniifolia can be visited for pollen. Dórea et al. $(2010 \mathrm{a}, \mathrm{b})$ considered B. vaciniifolia as an important oil source for C. tarsata and C. analis in a natural Caatinga vegetation and as an important local pollen source for $C$. analis due to the high frequency of that pollen type.

The high relative frequency of $M$. emarginata pollen in samples of larval provisions every month apparently was not directly dependent on the amount of acerola flowers in the orchard because $M$. emarginata was numerically impor$\operatorname{tant}(>90 \%)$ in the diet of larvae of $C$. analis even in months of low flower production. Bees nesting in our trap nests may have collected pollen also from nearby acerola orchards, and the sampling of 14 marked plants may not have been enough to characterize the periods of flower production in the entire region.

The pollen spectrum registered in the nests of $C$. analis suggested females exploiting several sources of nectar throughout the sampling period. Plant species related to the pollen types $A$. occidentale, Bowdichia virgilioides, Melochial Waltheria type 1, and Passiflora, which had higher temporal constancy but low monthly 
relative frequencies, are probably the most important sources of nectar for larvae of $C$. analis in that area. Some of these plants have been identified as sources of nectar for bees (Aguiar et al. 2003; Novais et al. 2009).

At first sight, the composition of larval provisions of $C$. analis seems to suggest that it engages in a broadly polylectic foraging behavior (characterized by the collection and use of pollen from several plant genera and species, including many non-phylogenetically related ones) because a high richness of pollen types associated with a variety of botanical families was found in the provisions. These results corroborate those obtained in the long-term study conducted by Roubik and Villanueva-Gutiérrez (2009). On the other hand, only part of the pollen types found in nests of $C$. analis indicate the pollen resources used by the species (Dórea et al. 2010a; this study). Therefore, in order to draw consistent conclusions about the degree of polylecty of a bee species, we must analyze not only the richness of pollen types but mainly the relative frequency of each pollen type in nests. This would grant greater support for the inferences concerning the number of pollen sources the species uses to provision its brood cells. Furthermore, the accurate description of the important pollen spectrum for each bee species can only be undertaken after multi-annual studies are conducted, which may show substitutions in the major pollen between years.

\subsection{Trophic niche breadth of larvae}

The high frequency of the pollen-type $M$. emarginata in larval provisions of $C$. analis strongly influenced trophic niche breadth $\left(H^{\prime}\right)$ and the equitativity $\left(J^{\prime}\right)$ in floral resource use by the bee in time. The highest $H^{\prime}$ and $J^{\prime}$ values were observed in months when less pollen grains of $M$. emarginata were found in nests of $C$. analis and more intensive foraging for pollen from alternative floral resources occurred. On the contrary, low niche breadths were registered in months with strong predominance of pollen of $M$. emarginata in larval provisions of $C$. analis, independently of the number of floral resource sources (inferred by the number of pollen types) used by females of this species of Centris in any specific month.

Results from a study by Rabelo et al. (2012), on the niche breadth in $C$. analis based on larval provisions in two areas covered by Cerrado vegetation in Brazil, were $H^{\prime}=0.78$ (ESAL) and $H^{\prime}=0.95$ (PES). The niche breadth $\left(H^{\prime}\right)$ for larvae of $C$. analis in Feira de Santana was relatively higher $\left(H^{\prime}=1.24\right)$ than in these two Cerrado areas. Few pollen types had high relative frequency in the samples, in Feira de Santana, ESAL, and PES, indicating that foraging for pollen was concentrated on a few plants. In Feira de Santana, $M$. emarginata pollen had a high level of representation $(\sim 76 \%)$, whereas in both Cerrado areas, native species of Malpighiaceae (Heteropterys spp.) were the most frequent pollen types (80\% of the grains at ESAL and $70 \%$ at PES).

Quiroz-Garcia et al. (2001) found, in a tropical decidual forest in Mexico, a trophic niche breadth to $C$. analis $\left(H^{\prime}=1.58\right)$ higher than the value we found in the semiarid Brazilian northeast $\left(H^{\prime}=1.24\right)$, even though the richness of pollen types they found into the nests was about half of what we found (17 versus 36 ). Few pollen types were represented over $10 \%$ in the larval provisions of $C$. analis in both of these studies, and that has affected the values of the $H^{\prime}$ index down. On the other hand, Roubik and Villanueva-Gutiérrez (2009) found 72 pollen types in nests of $C$. analis, which could result in greater niche breadth than those found in other studies.

\subsection{Final considerations}

The presence of $M$. emarginata in the larval provisions of $C$. analis means that acerola provides the pollen and floral oils needed by the pollinator throughout the year in the region. However, supplemental pollen sources are needed in the periods of flower scarcity in non-irrigated crops, which can be solved by intercropping acerola and pigeon pea (C. cajan) in small farms, in addition to agricultural practices friendly to pollinators, which provide pollinator bees with higher pollen and nectar production, such as the maintenance of stripes of ruderal plants around the 
orchards. Nectar demand by $C$. analis and other crop pollinators can be supplied by encouraging the growth of plants that can offer nectar abundantly, such as the cashew tree (A. occidentale), which can be used both for human consumption and for the local small-scale economy.

\section{ACKNOWLEDGMENTS}

We thank the National Council for Scientific and Technological Development, Brazil (CNPq, proc. no. 475715/2008-0, no. 562518/2010-0), and the Fundação de Amparo à Pesquisa do Estado da Bahia (FAPESB, TO APP0042/2009) for financial support for this project. C.M.L. Aguiar, F.A. Santos, and S.C. Augusto received research fellowship from CNPq. R.M. Santos and G.F. Almeida received MSc scholarship and postdoctoral scholarship from FAPESB.

Les provisions de la larve du pollinisateur Centris analis: spectre pollinique et étendue de la niche trophique dans un agro-écosystème

Palynologie et entomologie / ressources florales / abeille solitaire / Centridini / pollinisateur des cultures

Das Larvenfutter des Feldfruchtbestäubers Centris analis: Pollenspektrum und Breite der trophischen Nische in einem Agroökosystem

Entomopalynologie / Blütenquellen / solitäre Bienen / Centridini / Feldfruchtbestäuber

\section{REFERENCES}

Aguiar, C.M.L., Zanella, F.C.V., Martins, C.F., Carvalho, C.A.L. (2003) Plantas visitadas por Centris spp. (Hymenoptera: Apidae) na caatinga para obtenção de recursos florais. Neotrop. Entomol. 32, 247-259

Cane, J., Sipes, S. (2006) Characterizing floral specialization by bees: analytical methods and a revised lexicon for oligolecty. In: Waser, N., Ollerton, J. (eds.) PlantPollinator Interactions: From Specialization to Generalization, pp. 99-122. The University of Chicago Press, Chicago

CEI-Centro de Estatística e Informações, Bahia (1994) Informações Básicas dos Municípios Baianos: Região Paraguaçu, CEI, Salvador, 877 pp
Cortopassi-Laurino, M., Ramalho, M. (1988) Pollen harvest by Africanized Apis mellifera and Trigona spinipes in São Paulo: botanical and ecological views. Apidologie 19, 1-24

Cortopassi-Laurino, M., Zillikens, A., Steiner, J. (2009) Pollen sources of the orchid bee Euglossa annectans Dressler 1982 (Hymenoptera, Apidae, Euglossini) analyzed from larval provisions. Genet. Mol. Res. 8, 546-556

Colwell R.K. (2005) EstimateS. Statistical estimation of species richness and shared species from samples, V. 7.5.2. http://viceroy.eeb.uconn.edu/EstimateSPages. Accessed January 2008

Dórea, M.C., Aguiar, C.M.L., Figueroa, L.E.R., Lima, L.C.L., Santos, F.A.R. (2010a) Pollen residues in nests of Centris tarsata Smith (Hymenoptera, Apidae, Centridini) in a tropical semiarid area in NE Brazil. Apidologie 41, 557-567

Dórea, M.C., Aguiar, C.M.L., Figueroa, L.E.R., Lima, L.C.L., Santos, F.A.R. (2010b) Residual pollen in nests of Centris analis (Hymenoptera, Apidae, Centridini) in an area of caatinga vegetation from Brazil. Oecol. Aust. 14, 232-237

Erdtman, G. (1960) The acetolysis method. A revised description. Sven. Bot. Tidskr. 54, 561-564

Freitas, B.M., Paxton, R.J. (1998) A comparison of two pollinators: the introduced honey bee Apis mellifera and an indigenous bee Centris tarsata on cashew Anacardium occidentale in its native range of $\mathrm{NE}$ Brazil. J. Appl. Ecol. 35, 109-121

Freitas, B.M., Alves, J.E., Brandão, G.F., Araújo, Z.B. (1999) Pollination requirements of West Indian cherry (Malpighia emarginata) and its putative pollinators, Centris bees, in NE Brazil. J. Agric. Sci. 133, 303-311

Freitas, B.M., Paxton, R.J., Holanda-Neto, J.P. (2002) Identifying pollinators among an array or flower visitors, and the case of inadequate cashew pollination in NE Brazil. In: Kevan, P., Imperatriz-Fonseca, V.L. (eds.) Pollinating Bees-The Conservation Link Between Agriculture and Nature, pp. 224229. Ministry of Environment, Brasilia

Gaglianone, M.C. (2005) Nesting biology, seasonality, and flower hosts of Epicharis nigrita (Friese, 1900) (Hymenoptera: Apidae: Centridini), with a comparative analysis for the genus. Stud. Neotropical Fauna Environ. 40, 191-200

Gaglianone, M.C., Rocha, H.H.S., Benevides, C.R., Junqueira, C.N., Augusto, S.C. (2010) Importância de Centridini (Apidae) na polinização de plantas de interesse agrícola: o maracujá-doce (Passiflora alata Curtis) como estudo de caso na região sudeste do Brasil. Oecol. Aust. 14, 152-164

Gonçalves, L., Silva, C.I., Buschini, M.L.T. (2012) Collection of pollen grains by Centris (Hemisiella) tarsata Smith (Apidae: Centridini): is C. tarsata an oligolectic or polylectic species? Zool. Stud. 51, 195-203

Jesus, B.M.V., Garófalo, C.A. (2000) Nesting behaviour of Centris (Heterocentris) analis (Fabricius) in southeast- 
ern Brazil (Hymenoptera, Apidae, Centridini). Apidologie 31, 503-515

Joosten, H., Klerk, P. (2002) What's in a name? Some thoughts on pollen classification, identification, and nomenclature in quaternary palynology. Rev. Palaeobot. Palynol. 122, 29-45

Oliveira, R., Schlindwein, C. (2009) Searching for a manageable pollinator for acerola orchards: the solitary oil-collecting bee Centris analis (Hymenoptera: Apidae: Centridini). J. Econ. Entomol. 102, 265-273

Novais J.S., Lima e Lima L.C., Santos F.A.R. (2009) Botanical affinity of pollen harvested by Apis mellifera L. in a semi-arid area from Bahia, Brazil. Grana, 48, 224-234

Quiroz-Garcia, D.L., Martinez-Hernandez, E., PalaciosChavez, R., Galindo-Miranda, N.E. (2001) Nest provisions and pollen foraging in three species of solitary bees (Hymenoptera: Apidae) from Jalisco, México. J. Kansas Entomol. Soc. 74, 61-69

Quiroz-Garcia, D.L., de la Arreguin-Sánchez, M.L. (2006) Resource utilization by Centris flavofasciata Friese (Hymenoptera: Apidae) in Jalisco, México. J. Kansas Entomol. Soc. 79, 249-253

Rabelo, L.S., Vilhena, A.M.G.F., Bastos, E.M.A.F., Augusto, S.C. (2012) Larval food sources of
Centris (Heterocentris) analis (Fabricius, 1804) (Hymenoptera, Apidae), an oil-collecting bee. J. Nat. Hist. 46, 1129-1140

Ramalho, M., Kleinert-Giovannini, A., ImperatrizFonseca, V.L. (1989) Utilization of floral resources by species of Melipona (Apidae, Meliponinae): floral preferences. Apidologie 20, 185-195

Ribeiro, E.K.M.D., Rêgo, M.M.C., Machado, I.C.S. (2008) Cargas polínicas de abelhas polinizadoras de Byrsonima chrysophylla Kunth. (Malpighiaceae): fidelidade e fontes alternativas de recursos florais. Acta Bot. Bras. 22, 165-171

Roubik, D.W., Villanueva-Gutiérrez, R. (2009) Invasive Africanized honey bee impact on native solitary bees: a pollen resource and trap nest analysis. Biol. J. Linn. Soc. Lond. 98, 152-160

Vilhena, A.M.G.F., Rabelo, L.S., Bastos, E.M.A.F., Augusto, S.C. (2012) Acerola pollinators in the savanna of Central Brazil: temporal variations in oilcollecting bee richness and a mutualistic network. Apidologie 4, 51-62

Vinson, S.B., Frankie, G.W. (2000) Nest selection, usurpation, and a function for the nest entrance plug of Centris bicornuta (Hymenoptera: Apidae). Ann. Entomol. Soc. Am. 93, 254-260 